\title{
ARSENIC CONTENT IN FIVE SEDIMENT PROFILES FROM ADMIRALTY BAY, KING GEORGE ISLAND, ANTARCTICA
}

http://dx.doi.org/10.4322/apa.2014.011

\author{
Andreza P. Ribeiro ${ }^{*}$, Rubens C. L. Figueira ${ }^{1}$, César C. Martins², Charles R. A. Silva ${ }^{1}$, \\ Elvis J. França ${ }^{1}$, Márcia C. Bícego ${ }^{1}$, Michel M. Mahiques ${ }^{1}$, Rosalinda C. Montone ${ }^{1}$ \\ ${ }^{1}$ Instituto Oceanográfico, Universidade de São Paulo - USP, São Paulo, SP, Brazil \\ ${ }^{2}$ Centro de Estudos do Mar, Universidade Federal do Paraná - UFPR, Pontal do Paraná, PR, Brazil \\ *e-mail: aportellar@yahoo.com.br
}

Admiralty Bay is the largest bay on King George Island, Antarctica, with a total area of around $131 \mathrm{~km}^{2}$ and maximum depth of $530 \mathrm{~m}$. This region is of utmost importance for studies of environmental quality assessment because of the presence of scientific research stations in this region. Since the early 80 's scientific research has been focused on the Brazilian Antarctic Station "Comandante Ferraz". In addition, the Polish Station Henry Arctowiski (Ezcurra Inlet) and the Peruvian Machu Picchu Station are also based in the bay. All activities require the consumption of fossil fuel for their operation. Fossil fuel is recognized as an important input of major pollutants (organic compounds) and trace elements ( $\mathrm{As}, \mathrm{Cd}, \mathrm{Cu}, \mathrm{Pb}$ and $\mathrm{Zn}$ ). Among trace elements, arsenic is highly toxic even in low concentration in the environment. Accordingly, this work presents the results of arsenic in 92 samples, representing five sediment profiles from different sites (Comandante Ferraz Station, Botany Point, Ulmann Point, Arctowski Station and Barrel Point) in Admiralty Bay. The highest As content was observed for Barrel Point profile (ranging from 7 to $\left.11 \mathrm{mg} \cdot \mathrm{kg}^{-1}\right)$. Otherwise, by using the enrichment factor and the geochronology analysis, the Brazilian Antarctic Station presented the most relevant enrichment for this metalloid, suggesting its increase due to the human activities in the bay.

Studies on contamination of aquatic systems have been focused on sediments, because this layer acts as a reservoir for many chemical substances, such as metals and metalloids. The depositional feature of the elements in the sediment gives a fingerprint of the contamination, providing information on the history of the contamination (Dinescu et al, 1998; Banin et al, 1998; Ribeiro et al, 2005). However, tracing the origin of the contaminants is not an easy task since the determination of background concentrations of chemical elements (in a range of environmental matrices, including sediments) are based on degree of temporal and spatial variability of a small number of samples. Sampling might not be representative of the whole studied area, in which local variance can exceed the analytical uncertainty, thereby increasing the complexity of geochemical fingerprint studies (Gasparon and Matschullat, 2006).

A large number of studies have certainly reported the impact of human activities on the Antarctic environment. However, studies for determining baseline levels of metals and metalloids are still scarce. Furthermore, information from available data sets of the impacted sites is often applied to estimate the elemental levels at a regional scale. As a result, the elemental Antarctic baseline values may have exceeded the natural content in the region. Therefore, the development of studies to distinguish anthropogenic and natural sources from metals and metalloids in the Antarctic environment has become a concern and an important issue for the international scientific community (Gasparon and Matschullat, 2006).

The Admiralty Bay located in King George Island is the largest embayment in the South Shetland Islands, which 
presents the character of a ford, with a branching system of inlets. There are three branches: Ezcurra Inlet to the south-west; Mackellar Inlet to the north; and Martel Inlet in the north-east (Rakusa-Suszczewski, 1980). The bay has three research stations, Arctowski, Comandante Ferraz and Macchu Picchu, which are operated by Poland, Brazil and Peru, respectively (Montone et al., 2001; Santos et al., 2006; Martins et al, 2010).

The Brazilian Antarctic Station "Comandante Ferraz" consumes 320,000 L of Arctic-grade diesel oil, with a mean monthly consumption of around 23 tons of fuel (Bícego et al., 2009). Further, incinerator and vehicular exhaust emissions are potential sources of polycyclic aromatic hydrocarbons (PAHs) in the region. The Arctowski Station consumes about 100,000 L of diesel fuel per year. The lowest consumption is observed for the Peruvian Macchu Picchu Station due to its operation only in the austral summer (COMNAP, 2008). Therefore, the current consumption of fossil fuel by the research stations poses a potential risk of direct release of organic compounds and trace elements into the environment (Fishbein, 1981; Vouk and Piver, 1983; Bícego et al., 2009; Taniguchi et al., 2009).

Among the trace elements, arsenic is widely distributed in the environment and highly toxic, being considered the king of poisons. In fact, diverse anthropogenic sources have been studied for increasing the cycling of As in the environment (Niagru et al., 2007), including fossil fuel (Vouk and Piver, 1983). Therefore, the aim of this study has been to investigate the behaviour of the metalloid As in sediment profiles from Antarctica. The enrichment factor and the geochronology analysis were used to assess anthropogenic and/or natural sources of As in the samples. The profiles were collected in five sampling sites (Table 1) distributed in Admiralty Bay (Figure 1), during the $25^{\text {th }}$ Brazilian Antarctic Expedition in the 2006/2007 austral summer (Martins et al., 2010).

Samples were taken from upper and lower zones of sediment profiles. From the upper zone, the profiles were sliced into $1 \mathrm{~cm}$ layers (subsamples). Afterwards, the samples were analyzed by Inductively Coupled
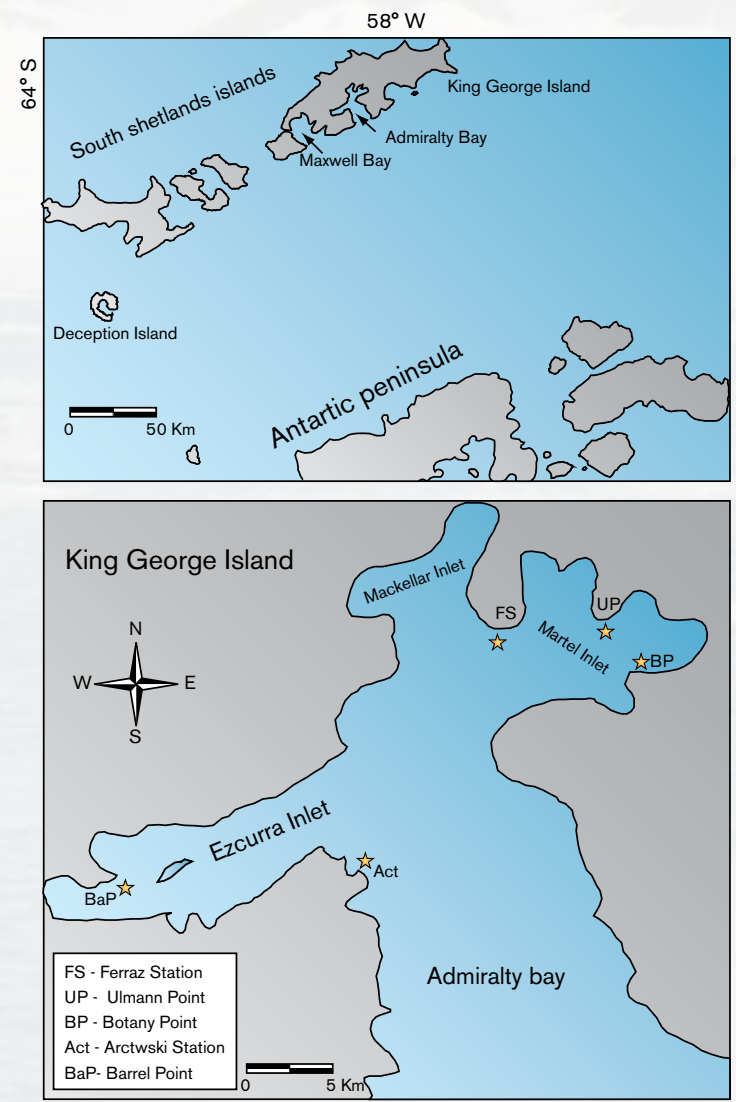

Figure 1. Study area and sampling sites in Admiralty Bay, King George Island.

Table 1.The geographical description of the sampling units for sediment profile sampling at Admiralty Bay, King George Island, Antarctic Peninsula

\begin{tabular}{|c|c|c|c|c|c|}
\hline Site & Name & Latitude & Longitude & $\begin{array}{l}\text { Profile depth } \\
\text { (m) }\end{array}$ & $\begin{array}{l}\text { Sedimentation Rate } \\
\left(\mathrm{cm} . \text { year }^{-1}\right)\end{array}$ \\
\hline 1 & C.Ferraz Station (FS) & $62^{\circ} 05.033^{\prime} \mathrm{S}$ & $058^{\circ} 22.898^{\prime} \mathrm{W}$ & 40 & $0.35 \pm 0.03$ \\
\hline 2 & Botany Point (BP) & $62^{\circ} 05.841^{\prime} \mathrm{S}$ & $058^{\circ} 20.320^{\prime} \mathrm{W}$ & 30 & $0.28 \pm 0.03$ \\
\hline 3 & Ulmann Point (UP) & $62^{\circ} 05.530^{\prime} \mathrm{S}$ & $058^{\circ} 20.100^{\prime} \mathrm{W}$ & 20 & $0.11 \pm 0.01$ \\
\hline 4 & Arctowiski Station (Act) & $62^{\circ} 10.410^{\prime} \mathrm{S}$ & $058^{\circ} 31.245^{\prime} \mathrm{W}$ & 20 & $0.13 \pm 0.03$ \\
\hline 5 & Barrel Point (BaP) & $62^{\circ} 10.274^{\prime} S$ & $058^{\circ} 35.504^{\prime} \mathrm{W}$ & - & $0.33 \pm 0.01$ \\
\hline
\end{tabular}


Plasma - Optical Emission Spectrometry (ICP OES). The methodology for determining the trace elements was based on the digestion method 3050A (USEPA, 1996). For estimating the sedimentation rate, High Resolution Gamma Ray Spectrometry (HRGRS) was applied to determine ${ }^{137} \mathrm{Cs}$ after 30 days in order to achieve secular equilibrium (Figueira, 1998). Table 1 presents the sedimentation rates for the profiles collected in Admiralty Bay.

Table 2 shows the content ranges of As in 92 sediment samples of the profiles from different sites in the Admiralty Bay. Furthermore, the data set was compared with literature values available elsewhere (Table 2) for the Antarctic Environment. Arsenic was in the same order of magnitude of previous contents already published by specialized literature. Otherwise, the highest contents of As were observed by Santos et al (2007) in sediments from the Brazilian Antarctic Comandante Ferraz Station.

Figure 2 presents the distribution of chemical elements in the profiles, in which As in $\mathrm{BaP}$ and FS sediments were slightly higher than the other sampling sites. Previous studies have related the local pollution with hydrocarbon caused by accidents during fuel transference within the Antarctic environment. These events could also contribute for the As enrichment in the region (Bargagli, 2005).

In spite of the difficulty of understanding the association among trace elements and mineralogy of sediments, the contamination of sediments was evaluated through the calculation of the enrichment factor - EF (Salomons and Förstner, 1984). Normalizers, such as Al, $\mathrm{Li}, \mathrm{Fe}$ and Sc, have been widely employed to estimate the anthropogenic contribution for the chemical element distribution in the sediment profiles (Dinescu et al, 1998; Banin et al, 1998; Ribeiro et al, 2005). Here, samples from the lower zone of sediment profiles as well as the normalizer Sc were used in the calculations. In this analysis, five-category ranking is commonly adopted to denote the degree of anthropogenic contamination: EF values lower than 2 indicates minimum contamination; $\mathrm{EF}$ in the range of $2-5$, moderate contamination; $\mathrm{EF}$ in the range of $5-20$, significant contamination; EF in the order of 20 - 40, very high contamination, while EF higher than 40, extremely high contamination (Sutherland 2000; Liu et al., 2010).
Table 2. Trace element ranges $\left(\mathrm{mg} \mathrm{kg}^{-1}\right)$ determined in the Antarctic sediments and compared with literature values

\begin{tabular}{|c|c|}
\hline Site & As (mg.kg $\left.{ }^{-1}\right)$ \\
\hline Admiralty Bay ${ }^{1}$ & $2-12$ \\
\hline C.Ferraz ${ }^{2}$ & $8-23$ \\
\hline Botany ${ }^{3}$ & $4-6$ \\
\hline Mc Murdo Station ${ }^{4}$ & $4-5$ \\
\hline Princess Regnheld Station ${ }^{5}$ & $4-7$ \\
\hline
\end{tabular}

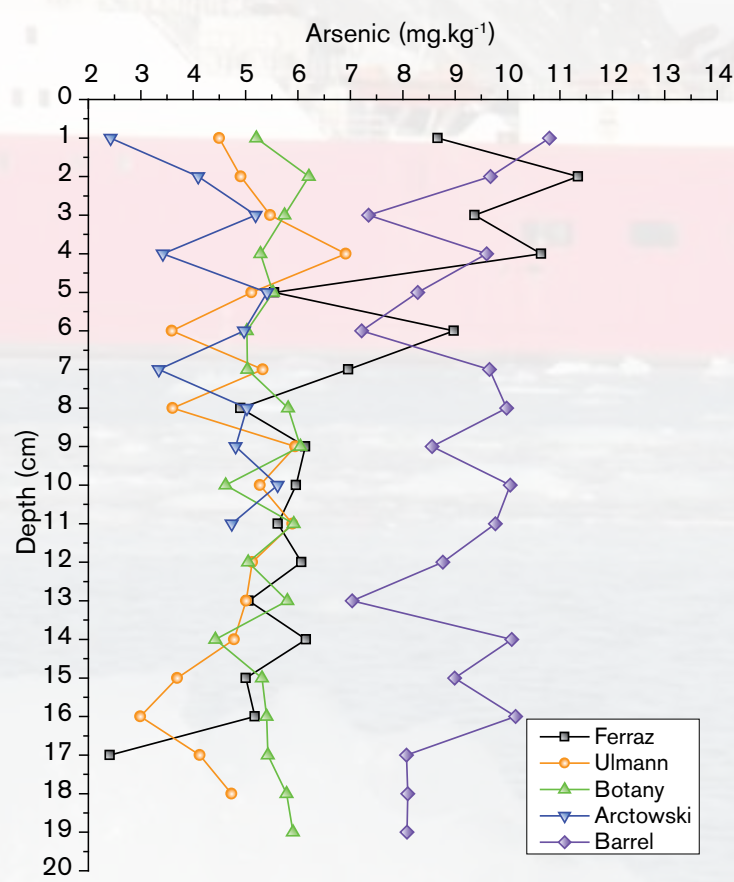

Figure 2. Arsenic contents (mg kg-1) in the sediment profiles from the Admiralty Bay.

According to Figure 3, the enrichment was observed mainly for As at the Comandante Ferraz Station during the period between 1986 and 2006.

Comandante Ferraz Station was built in the summer of 1984 on the eastern coast of the Keller Peninsula. Firstly, the station was planned to have eight containers for accommodating only 12 researchers. After one year, the station was expanded to 33 containers for the accommodation of about 30 people. Nowadays, the Brazilian Antarctic station has a building area of 2,250 $\mathrm{m}^{2}$ with capacity for 56 people (Weber and Montone, 2006).

Therefore, as mentioned above, a large amount of fossil fuel has been needed for the maintenance of the scientific station. Considering the enrichment of As (ranging 
from 0.5 to 2.3 ) started in 1986 , this human activity was suggested as a potential source of this chemical element in the Antarctic ecosystem. Nevertheless, the As levels in sediment profiles agreed with the shale reference level of $13 \mathrm{mg} \mathrm{kg}^{-1}$ (Turekian and Wedepohl, 1961) and results from other studied sites, in which there were no indication of relevant anthropogenic impacts (Turekian and Wedepohl, 1961, Waheed et al., 2001; Santos et al., 2005; Abrahim and Parker, 2008).

As observed for the Comandante Ferraz Station, Barrel Point (Figure 3) also presented some enrichment; however, EF values ranged from 1.2 to 1.9 have indicated no anthropogenic contamination in Barrel Point.
Despite some samples presenting high As content values, the vertical distribution pattern was considered similar for all sediment profiles since EF values were in the range of $0.3-2$ (Figure 3). Therefore, results indicated a local dependence and slight association of human activities with the increase of As concentrations in Admiralty Bay.

Valuable information has been provided for environmental monitoring, controlling and preventing environmental contamination based on the determination of labile fractions of arsenic in sediments from Antarctica.
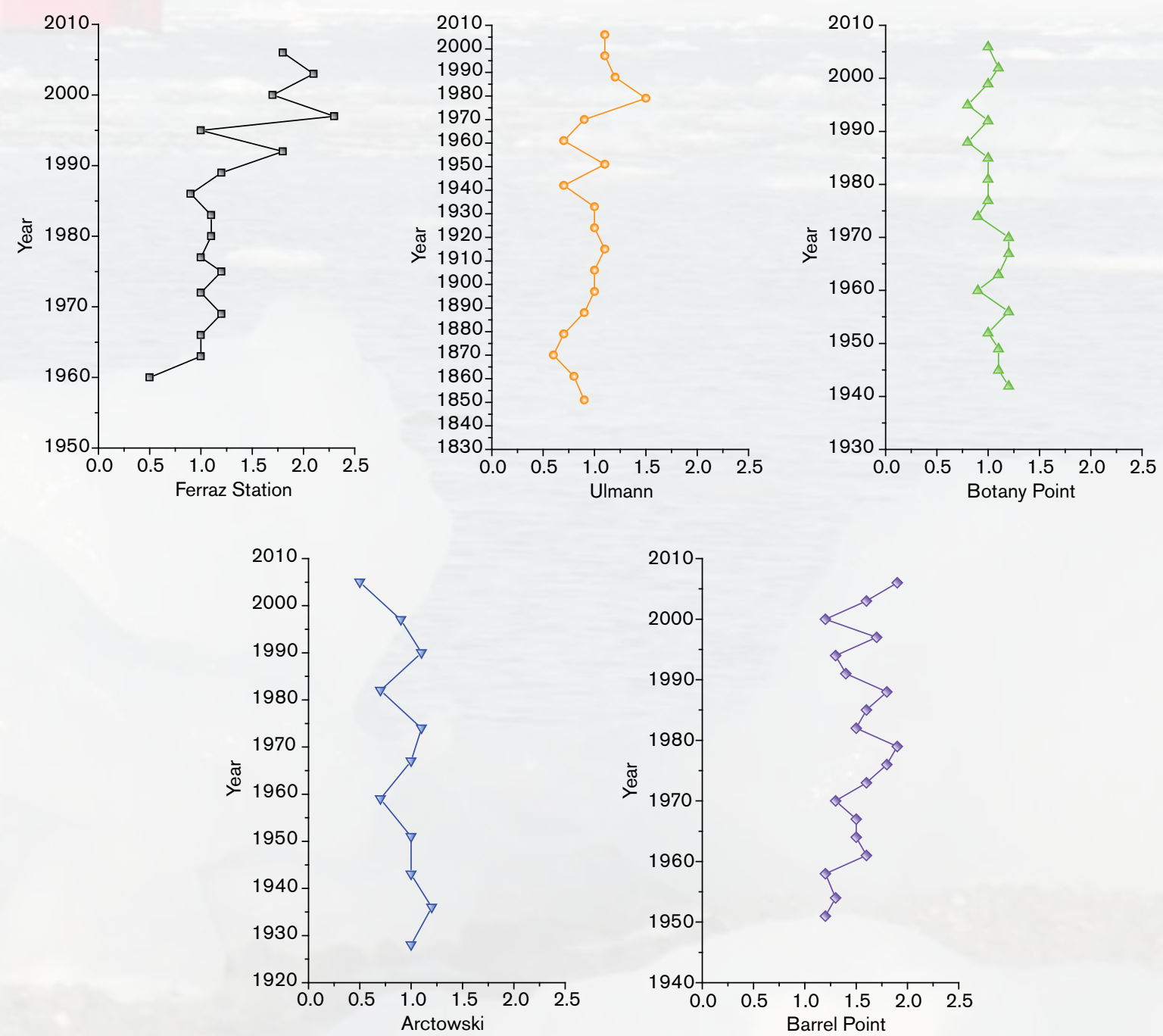

Figure 3. Enrichment factor (EF) according to the sediment dating for arsenic. 


\section{References}

ABRAHIM, G. M. S.; PARKER, R. J. Assessment of heavy metal enrichment factors and the degree of contamination in marine sediments from Tamaky Estuary, Auckland, New Zealand. Environmental Monitoring and Assessment, v. 136, p. 227-238, 2008.

BANIN, A.; ESHEL, G.; ROEHL, K. E. Heavy metal and trace element adsorption to recharge basin soils of Shafdan reclamation project. Report. 1997-1998. 215 p.

BARGAGLI, R. Antarctic Ecosystems Environmental Contamination: Climate Change, and Human Impact. Springer: Ecological Studies, 2005. v. 175, 397 p. 2005.

BÍCEGO, M. et al. Results from a 15-year study on hydrocarbon concentrations in water and sediment from Admiralty Bay, King George Island, Antarctica. Antarctic Science, v. 21, p. 209-220, 2009.

COUNCIL OF MANAGERS OF NATIONAL ANTARCTIC PROGRAMS - COMAP. Main Antarctic facilities operated by National Programs in the Antarctic Treaty area (south 600 S). 2008. Available from: <http://www.comnap.aq/ facilities>.

DINESCU, L. C. et al. Investigation of the vertical distribution of major and trace elements in Matita Lake (Danube Delta) sediments by activation analysis. Journal of Radioanalytical and Nuclear Chemistry, v. 238, p. 75-81, 1998.

FIGUEIRA, R. C. L. et al. Goiânia, ten years later. Instrumental Analysis by Gamma Spectrometry of low level Cs137 in marine samples. Viena, 1998. p. 327-329.

FISHBEIN, L. Sources, transport and alterations of metal compounds: an overview I. Arsenic, beryllium, cadmium, chromium and nickel. Environmental Health Perspectives, v. 40, p. 43-64, 1981.

GASPARON, M.; MATSCHULLAT, J. Geogenic sources and sinks of trace metals in the Larsemann Hills, East Antarctica: Natural processes and human impact. Applied geochemistry: journal of the International Association of Geochemistry and Cosmochemistry, v. 21, p. 318-334, 2006

LIU, E.; SHEN, J.; YANG, L. Assessment of heavy metal contamination in the sediments of Nansihu lake catchment, China. Environmental Monitoring and Assessment, v. 161, p. 217-227, 2010.

MARTINS, C. C. et al. Historical record of polycyclic aromatic hydrocarbons (PAHs) and spheroidal carbonaceous particles (SCPs) in marine sediment cores from Admiralty Bay,King George Island, Antarctica. Environmental Pollution, v. 158, p. 192-200, 2010.

MONTONE, R. C.; TANIGUCHI, S.; WEBER, R. R. Polychorinated biphenyls in marine sediments of Admiralty Bay, King George Island, Antarctica. Marine Pollution Bulletin, v. 42, p. 611-614, 2001.

NEGRI, A. et al. Contamination in sediments, bivalves and sponges of McMurdo Sound, Antarctica. Environmental Pollution, v. 43, p. 456-467, 2006.

NRIAGU, J. O. et al. Arsenic in Soil and Groundwater Environment. In: Bhattacharya, P. et al. (Eds.). Trace Metals and other Contaminants in the Environment. [s.n.]: Elsevier, 2007. p. 3-60.

RAKUSA-SUSZCZEWSKI, S. Environmental conditions and functioning of Admiralty Bay (South Shetland Islands) as part of the near shore Antarctic ecosystem. Polish Polar Research, v. 1, p. 11-27, 1980.

RIBEIRO, A. P.; FIGUEIREDO, A. M. G.; SÍGOLO, J. B. Determination of heavy metals and other trace elements in lake sediments from a sewage treatment plant by neutron activation analysis. Journal of Radioanalytical and Nuclear Chemistry, v. 263, p. 645-651, 2005.

SALOMONS, W.; FÖRSTNER, U. Metals in the hydrocycle. Berlin: Springer-Verlag, 1984. 349 p.

SANTOS, I. R. et al. Sediment geochemistry in coastal maritime Antarctica (Admiralty Bay, King George Island): Evidence from rare earths and other elements. Marine Chemistry, v. 107, p. 464-474, 2007. 
SANTOS, I. R. et al. Baseline mercury and zinc concentrations in terrestrial and coastal organisms of Admiralty Bay, Antarctica. Environmental Pollution, v. 140, p. 304-311, 2006.

SANTOS, I. R. et al. Heavy metal contamination in coastal sediments and soils near the Brazilian Antarctic Station, King George Island. Marine Pollution Bulletin, v. 50, p. 185-194, 2005.

SUTHERLAND, R. A. Bed sediment-associated trace metals in a urban stream, Oahu, Hawaii. Environmental Geology, v. 39, p. 611-627, 2000.

TANIGUCHI, S. et al. Chlorinated pesticides, polychlorinated biphenyls and polycyclic aromatic hydrocarbons in the fat tissue of seabirds from King George Island, Antarctica. Marine Pollution Bulletin, v. 58, p. 129-133, 2009.

TUREKIAN, K. K.; WEDEPOHL, D. H. Distribution of the elements in some major units of earth's crust. Bulletin Geological Society of America, v. 72, p. 175-192, 1961.

UNITED STATES ENVIRONMENTAL PROTECTION AGENCY - US-EPA. Method 3050B. Acid digestion of sediments, sludges and soil. Revision 2. December, 1996.

VOUK, V. B.; PIVER, W. T. Metallic elements in fóssil fuel combustion products: amounts and form of emissions and evaluation of carcinogenicity and mutagenicity. Environmental Health Perspectives, v. 47, p. 201-225, 1983.

WAHEED, S. et al. Antarctic marine sediments as fingerprints of pollution migration. Journal of Radioanalytical and Nuclear Chemistry, v. 250, p. 97-107, 2001.

WEBER, R. R.; MONTONE, R. C. Gerenciamento ambiental na Baía do Almirantado, Ilha Rei George, Antártica. [s.n.]:[S.I.], 2006. 255 p. (CNPq-PROANTAR: Rede 2). 